\title{
La verdad de las imágenes
}

\author{
Josep M. Català Domènech \\ Catedrático de Comunicación Audiovisual \\ (Universitat Autònoma de Barcelona)
}

\section{Referencia de este artículo}

Català Domènech, Josep M. (2021). La verdad de las imágenes. En: adComunica. Revista Científica de Estrategias, Tendencias e Innovación en Comunicación, n ${ }^{0} 22$. Castellón de la Plana: Departamento de Ciencias de la Comunicación de la Universitat Jaume I, 365-368. DOI: http://dx.doi.org/10.6035/2174-0992.2021.22.18

"Cree a aquellos que buscan la verdad;

Duda de aquellos que la encuentran»

André Gide

La primera vez que tuve conocimiento del concepto de posverdad, mucho antes de que el Oxford Dictionary, lo popularizara, fue a través de un libro publicado cuyo título conservaba la versión francesa de esa acepción - postverité- y cuyo tema era el de las nuevas tendencias del cine documental (VV.AA, 2003), es decir, del medio donde reside, o residía, la esencia de la verdad cinematográfica. Recordemos, al respecto, lo que decía Jean Rouch sobre el cinéma-vérité: que no se refería tanto a un cine de la verdad, cuanto a una verdad del cine. Esta verdad del cine es la raíz de la verdad de la imagen contemporánea en general.

Me gustaría poder decir que existe una gran confusión sobre el concepto de posverdad, pero lo cierto es que, cuando fue asimilada y difundida por los medios de 
comunicación, la posible ambigüedad fue inmediatamente desactivada, de modo que lo único que ha quedado de esa noción ha sido su sesgo negativo. Al empobrecimiento del debate ha contribuido sin duda la introducción de las llamadas fake news o noticias falsas que han constituido la columna vertebral de la era Trump y su perverso debate ideológico.

Es cierto que, en el momento en que se cuestiona la prevalencia de la verdad, se abre la puerta a todo tipo de ambigüedades. Al fin y al cabo, la posverdad hereda en el campo social la controversia filosófica sobre el relativismo. Pero las indeterminaciones no son malas en sí mismas, puesto que, al fin y al cabo, constituyen una de las características más esenciales de la ontología de cuyo seno surge la posverdad. No es solo que el régimen de la posverdad genere ambigüedades, sino que la ontología posfundacional, y por lo tanto antiautoritaria, abre la puerta al cuestionamiento de las verdades absolutas, es decir, a un pensamiento que ha superado el eje fundacional de la verdad. El problema es que en este ámbito la mentira puede campar fácilmente por sus respetos, hasta el punto de convertirse en sustituto de las antiguas verdades. De hecho, si las llamadas posverdades y derivados de ellas como las fake news son tan dañinas es porque aún se sigue creyendo en la existencia de verdades que compiten por el poder. Mal que nos pese, en la actualidad, el mejor remedio contra las noticias falsas y otras manipulaciones es la aceptación de las herramientas críticas que facilita el régimen de la posverdad.

La sesgada diatriba actual sobre la posverdad, ha hecho olvidar que la discusión viene de lejos y que, por tanto, existe una tradición crítica de gran calado que, en su versión contemporánea, va desde Foucault a Vattimo, si bien se proyecta sobre ella la alargada sombra de Nietzsche. Esta saga intelectual ha puesto de manifiesto la necesidad de superar una era que promulga la sumisión al principio de autoridad de aquellas instancias que pretenden detentar verdades absolutas. Como sea que el saber y el poder están íntimamente relacionados, no es de extrañar que se quiera investir al saber que se posee de una certeza prácticamente indiscutible. La posverdad, si consiguiéramos limpiarla de la mala fama acumulada a causa de lo que no son sino nuevas versiones de la propaganda y la desinformación empoderadas ahora por las redes sociales, aparecería como el emblema de un necesario paradigma crítico, capaz de asumir los retos de la complejidad contemporánea. Por el contrario, la proverbial superficialidad de los medios de información, así como la no menos conocida deshonestidad de ciertos políticos, ha convertido la era de la posverdad en un campo de minas.

En este controvertido contexto, aparece de nuevo la cuestión de las imágenes, concretamente la de la verdad de las imágenes. Las contemporáneas tecnologías de la imaginación, sustentadas por una visualidad digitalizada, son las nuevas acusadas en ese sempiterno tribunal al que se ve conminado a acudir cualquier nuevo medio que tenga alguna trascendencia cognitiva desde que, según expone Platón en el «Fedro», el dios Theuth recibió una reprimenda del rey Thamus por propo- 
ner la propagación de la escritura, una técnica, que según el rey, iba a degradar la memoria y a convertir todo saber en un conocimiento espurio. Una queja parecida se produjo con la invención de la imprenta, la cual iba a dificultar aún más el verdadero saber personal. Y no menos conocido es el extraordinario capítulo que Víctor Hugo, en El jorobado de Nôtre Dame, dedica a este tipo de episodios, cuando le hace exclamar al archidiácono de esa catedral la célebre predicción de que esto, refiriéndose al libro, acabará con esto otro, es decir, con el valor simbólico de la catedral. Lo que estaba diciendo el eclesiástico es que la imprenta acabaría con una tradición oral materializada por la arquitectura y, desde luego, controlada por la iglesia. Ceci tuera cela es el título de un libro de Annie Le Brun y Juri Armada en el que las autoras denuncian la ingente proliferación actual de imágenes, un fenómeno que implica la imposición de una economía distributiva de la imagen por la que «se aliena el contenido de esta, en provecho de su visibilidad» (Le Brun y Armanda, 2021). En este caso, se habría llegado al punto en el que la imagen, su proliferación y banalización, acabaría con la propia imagen, un incidente que Benjamin ya habría anunciado al exponer la pérdida del aura de las imágenes cuando estas son sometidas a la reproducción técnica. La era de la imagen y de las tecnologías de la imaginación serían, según este mito, el colofón de la serie de supuestas aboliciones de técnicas genuinas que habría iniciado la escritura, continuado la imprenta y ahora impondría no tanto la imagen, que ya fue criticada anteriormente - entre otros por Daniel Boorstin o Guy Debord, por citar solo los más conspicuos-, sino las tecnologías de la imagen o la imagen amplificada por la tecnología. Lo cierto es que la memoria, más que decaer, fue transformada por la escritura, de la misma manera que lo fue la oralidad por la imprenta. Ahora las tecnologías de la imagen y la imaginación están transformando la memoria, la escritura y la oralidad, así como la propia visualidad.

Es inútil seguir enfrentado a apocalípticos e integrados, según los parámetros establecidos por Umberto Eco, ya que, en las complejas situaciones actuales, ambos bandos acostumbran a tener parte de razón. Es cierto que, como apunta el apocalíptico volumen de Le Brun y Armanda, las imágenes, difundidas por las redes sociales, han perdido, no solo el aura, sino incluso su densidad acumulada durante siglos a través del arte, una consistencia que fue heredada y prolongada por el cine. Pero demonizar por ello las actuales formaciones visuales puede llegar a ser tan absurdo como criticar a las palabras por el hecho de que no siempre son usadas para confeccionar grandes obras literarias, sino que también son empleadas de manera muy superficial en las conversaciones cotidianas. El intercambio, a través de redes sociales como Facebook, Instagram o TikTok, de imágenes inmediatas — selfis o instantáneas capturadas por teléfonos móviles - puede considerarse una especie de conversación visual, es decir, una versión menos sabia de aquella actividad a la que se dedicaban, como exponía Swift en Los viajes de Gulliver, los habitantes de la isla de Laputa cuando querían conversar. Esos individuos, en lugar 
de intercambiar palabras, se mostraban objetos entre sí. Del mismo modo que el debate filosófico por medio de este trueque objetual no podía ir muy lejos - Swift pretendía satirizar el árido positivismo de una ciencia incipiente-, tampoco hay que pedirles a las actuales permutas de imágenes personales y efímeras la intensidad de un cuadro de Poussin o de una escena de Tarkovski.

Cuando Deleuze determinó que el cine constituía la imagen del pensamiento, desplazó de forma definitiva el eje de la reflexión desde el texto a la imagen. Era la imagen en movimiento la que mejor reflejaba la estructura de un pensamiento contemporáneo necesitado de amoldarse al ritmo cada vez más frenético de una realidad también en movimiento. No hay por tanto verdad de las imágenes, sobre todo de las imágenes de la era digital, promovidas por tecnologías de la imaginación, sino pensamiento visual. De la misma manera que la posverdad nos coloca ante la necesidad de pensar persiguiendo una certeza escurridiza, la imagen fluida de la nueva era visual propone la posibilidad de un pensamiento híbrido -imagen, palabra, sonido, visualidad, movimiento, gesto, cuerpo- que tiene su mejor representación en las formas de la interfaz que toma así el relevo del cine como imagen del pensamiento.

La imagen contemporánea ha perdido toda relación, ética o epistemológica, con la verdad. El cine documental ha sido el medio que mejor ha trazado este camino hasta la situación actual: durante su primera época, hasta los años sesenta, estuvo preocupado por la realidad: luego, después de que el aligeramiento de los aparatos le permitiera lo que parecía la conquista definitiva de lo real, pasó a ocuparse de la verdad. Actualmente, es un instrumento de las ideas (también de las ideologías) y del pensamiento.

Ahora la imagen solo puede mentir, sustentar noticias falsas o hechos alternativos, cuando se utiliza como instrumento de una supuesta verdad, es decir, cuando se la hace mentir. De lo contrario, constituye una herramienta privilegiada del saber, capaz de promover iluminaciones que otros medios u otras técnicas no son capaces alcanzar.

\section{Referencias}

Le Brun, Annie y Armanda, Juri (2021). Ceci tuera cela. Image, regard et capital. París: Éditions Stock.

V.V.A.A. (2003) Postvérité. Murcia: Centro Párraga. 